\title{
Special three processes of production and implementation
}

\author{
Nabiev Muzaffar Abdumalikovich \\ Applicant at Tashkent State University of Economics
}

\begin{abstract}
This article discusses theoretical considerations about the production and sale process in the automotive industry. Keywords : financial investments, stock, raw materials, cost, wholesale price, warehouse, finished products.
\end{abstract}

\section{Introduction}

The auto industry in our country has become one of the main factors in the economy. Today, the automotive industry, equipped with modern technology, implements a development strategy based on establishing profitable relationships with reputable companies around the world. This contributes to the production of competitive products to international standards.

According to the deputy chairman of Uzavtosanoat Azizbek Shukurov, the company has 75 companies. 40 of them are factories. The system employs 27,000 employees. By the end of 2018, \$ 3.5 billion was produced. This is about $8 \%$ of the country's GDP. Last year, 220,000 cars were produced in the country. This is twice as much as in 2017 . It is planned to release 250,000 cars this year.

GM Uzbekistan plays a special role in the development of the automotive industry of Uzbekistan. The company exports its products to Russia, Kazakhstan, Ukraine, Belarus, Azerbaijan, Georgia, Armenia, Tajikistan, Turkmenistan, Kyrgyzstan, Jordan, Lebanon, Iraq and several African countries. They established cooperation with South Korea, Brazil, the USA and European countries.

While in 2018, the company exported \$ 25.5 million. US auto parts and supplies, this year 118.6 million. The USA was localized with the release of more than 100 components. This will increase the level of localization by 3 industries and reduce annual imports by 14.6 million. Dollars.

This year it is planned to localize more than 240 parts. This will mean an annual reduction in imports of $\$ 17$ million.

This sets the task of accounting reform in this industry.

Accounting reform is a necessary method of economic reform for the transition from an administrative and managerial economy to the principles of a market economy.

Any management system, whether administrative or market, needs an appropriate information system.

Accounting is the most important source of information for collecting, recording, summarizing and making management decisions.

From this point of view, accounting is an essential element of the economic mechanism, and it is important to note that the organization of production accounting, which is its integral part, is one of the most natural problems of our time.

With the transition to market relations, various failures and uncertainties are revealed: this is the number of suppliers paid for their suppliers late in the evening, late in the evening. Reductions in the cache Reductions in the cache Reductions in the cache In addition, financial investments, the issuance and sale of private capital, currency and real estate transactions, dividend payments and other transactions are paid.

The enterprise needs to develop an effective data collection system for the timely and timely interpretation of these new data and views, and for it to be sustainable.

Accounting in the market and in the conditions of the isodiode is a modern, proprietary market function:

- firstly, in a market and ordinary economy, the form of ownership has changed, and interest in disputes of the enterprise has been paid to many new owners;

- Secondly, the Company was forced to seek a management path that would provide the necessary financial results for competition;

- Thirdly, financial services and loans are not the main source of financial resources for the enterprise.

Thus, the company competes with both the buyer and the market, as well as with the credit resources of commercial banks and other potential investors. As a result, on the one hand, there is a modern and complete information system for making management decisions and evaluating their results. on the market.

At the same time, it may be necessary to report individual discounts on market conditions to the state budget

Improving accounting in a market economy directly depends on the following factors: the formation of private property, the volatility of drugs, the quality of finished products, the development of the securities market, the influx of foreign investment, the integration of the national economy into the world economy. factors.

There are many tariffs for the role of accounting, the role and essence in practice and in economic theory.

For example, B. Needles provides the following tariffs: "Tracking, collecting, consolidating information on international business events for managing business processes. $\{1\}$ 
In this regard, an important tool is the organization of accounting in enterprises in accordance with international accounting standards.

All conditions for foreign investors, the creation of a regulatory framework and the widespread adoption of accounting standards are higher.

Sales of products is the final stage of the turnover of production capacities. A product for sale is called a product. One of the key indicators characterizing the business of the enterprise is the sale of goods. Commercial products include ready-to-eat products, semi-finished products, industrial work for consumers and enterprises.

Price is an expression of the value of money. Its basis is that which produces a particular product or product. Before the transition to market relations, there were three types of pricing of industrial goods:

Wholesale price of the enterprise;

Industrial wholesale prices;

retail price.

Market and economic conditions increased the price range: wholesale, in addition to retail, domestic prices were paid at the international level. The domestic price is the price set by the goods in the state, and the international price is the price fixed by the international price. In addition, we can talk about several different prices. For example, free price, statedetermined price, contract price, etc.

In the process of transition to a market economy, the price set by the state will be sharply reduced, and the range of free prices will increase. Enterprises that have achieved full independence seek to sell their products on the free market at a price agreed upon with consumers. The sale of goods through commodity goods is widely discussed at auction.

Accounting for items received at the warehouse and shipped to the customer's territory is reflected in the cost of production. However, when the goods come from the tanks to the warehouse, their actual cost is unknown, so you take into account the reverse charge of the goods. During the reporting month, the difference between actual costs and actual costs or the wholesale price is taken into account.

If the finished product is used in wholesale, retail and planned value, it is necessary to determine the difference between the actual value of the shipped and sold product and the accepted value. Synthetic accounting of finished products is registered 2800 "Finished products". The debit of this account is credited to the credit of the account "Basic production" and "Auxiliary production", and the credit is associated with the debit of the account "Cost of sales".

It is very important to use the list of the range of products manufactured by the enterprise for the correct accounting of the movement of finished products. The basis of its creation lies in the categorization of the finished product, that is, certain characteristics that distinguish one product from another. Below are the basics for compiling a list of items: model, brand, sorting, etc. Each item type is assigned an item number and it presents its number. Commodity nomenclature (list) is used in the following services of the enterprise:

- controls the performance of graphic products for dispatching services;

- workshops produced by workshops are controlled by an assortment of sleeping pills for toxicity of the warehouse;

- marketing knowledge - to control the possibility of execution of installation contracts;

- Accounting - An analytical report on the Thai product is used to collect information, general information and reports.

\section{List of used literature:}

1. Needles et al. "Mataupu Faavae o le Tausitusi", 1993.

2. Karimov A., Islamov F., Avlokulov A. Tausitusi. - Tashkent: NMAC "Sharq", 2004.

3. Quchqor Norqobil. Who Wakes the Sun ?: Stories. -T .: "East", 2007. -384 p.

4. Rasulov A. Art is a novelty. -T., "Sharq", 2007. - 336 p.

5. Serif Aktash. Introduction to novel art and novel insemination. - Ankara, 1991. - 162 B.

6. Izzat Sultan. Literary theory. - T., "Teacher", 2005. -272 p.

7. Faryono J.Vvedenie v literatturovedenie. Wster do literaturoznawstwa. - Wyd. II. - Warszawa, 1991. 